\title{
Epidemia provocada pelo vírus Zika: informação e conhecimento
}

\author{
Zika virus disease epidemic: information and knowledge \\ Epidemia de enfermedad causada por el virus de Zika: información y \\ conocimiento
}

\author{
Debora Diniz $\mid \underline{\text { d.diniz@anis.org.br }}$ \\ Universidade de Brasília. Brasília (DF), Brasil. \\ Anis - Instituto de Bioética, Direitos Humanos e Gênero. Brasília (DF), Brasil. \\ Luciana Brito | l.brito@anis.org.br \\ Anis - Instituto de Bioética, Direitos Humanos e Gênero. Brasília (DF), Brasil.
}

\section{Resumo}

Joselito e Maria Carolina vivem em Esperança, cidade no interior da Paraíba, e são pais de Maria Gabriela, criança nascida com a síndrome congênita do vírus Zika. O casal narra o itinerário de medicalização da vida familiar pela epidemia, e reclama "o direito ao conhecimento" como forma de proteção à vida. Nesta nota, argumentamos que o direito à informação é garantia fundamental para as pessoas afetadas pela epidemia, mas "conhecimento" pressupõe um marco amplo de reconhecimento que inclui o compartilhamento de proteções para uma vida digna.

Palavras-chave: Zika; acesso à informação; proteção social; precarização da vida; reconhecimento. 


\begin{abstract}
Joselito and Maria Carolina live in Esperança, a remote municipality of Paraíba, Brazil. They are the parents of Maria Gabriela, a little girl who was born with the syndrome associated with congenital Zika virus infection. The couple relate the itinerary of medicalization in family life caused by the epidemic, and claim "the right to knowledge" as a way to protect their life. We think that the right to information is a fundamental right of people affected by the epidemic, but "knowledge" presumes broad frontiers of recognition, including to share protections providing a life with dignity.
\end{abstract}

Keywords: Zika; acess to information; social protection; precarious life; recognition.

\title{
Resumen
}

Joselito y María Carolina viven en Esperanza, una pequeña ciudad en el interior de Paraíba, Brasil. Ellos son los padres de María Gabriela, una niña que nació con el síndrome asociado con la infección congénita por el virus Zika. La pareja relata el itinerario de la medicalización de la vida familiar causada por la epidemia y reclama el "derecho a saber" como una manera de proteger la vida. Pensamos que el derecho a la información es un derecho fundamental de las personas afectadas por la epidemia, pero el "conocimiento" presume un amplio marco de reconocimiento que incluye compartir protecciones para una vida con dignidad.

Palavras clave: Zika; acceso a la información; protección social; precariedad de la vida; reconocimiento.

Contribuição dos autores: Debora Diniz e Luciana Brito participaram da revisão e da redação do artigo.

Declaração de conflito de interesses: As autoras declaram que não há conflito de interesse.

Fontes de financiamentos: Não há.

Agradecimento/Contribuições adicionais: Não.

Apresentação anterior: Não.

Histórico do artigo: Submetido: 09.jun.2016 | Aceito: 11.jun.2016 | Publicado: 30.jun.2016.

Licença CC BY-NC atribuição não comercial. Com essa licença é permitido acessar, baixar (download), copiar, imprimir, compartilhar, reutilizar e distribuir os artigos, desde que para uso não comercial e com a citação da fonte, conferindo os devidos créditos de autoria e menção à Reciis. Nesses casos, nenhuma permissão é necessária por parte dos autores ou dos editores. 


\section{Introdução}

Joselito e Maria Carolina vivem em um sítio na cidade de Esperança, no sertão da Paraíbai. A filha mais nova do casal chama-se Maria Gabriela - conhecemos a família no Ambulatório de Microcefalia do Hospital Pedro I, em Campina Grande, centro de referência para as regiões do Sertão, do Alto Sertão e do Caririi ${ }^{\mathrm{ii}}$. A menina tem quatro meses e foi diagnosticada com a síndrome congênita do Zika. Duas vezes por semana, Maria Carolina viaja duas horas para levar a filha à terapia de estimulação precoce. Maria Gabriela já visitou médicos de tantas especialidades que os pais se perdem nos detalhes para antecipar os sinais e sintomas da nova doença no corpo da recém-nascida. Mãe e filha são a primeira geração afetada pela transmissão vertical do vírus Zika no Brasil.

A história do casal é típica e singular. Maria Carolina engravidou sem planos de ampliar a família. No primeiro trimestre da gravidez, apresentou os sintomas do vírus Zika, mas foi diagnosticada pelo serviço de saúde da cidade como portadora de uma "virose". Na primeira ecografia, o médico suspeitou de alterações morfológicas no feto e solicitou exames adicionais para o diagnóstico de má-formação. O casal os fez por conta própria, pois não eram oferecidos na rede pública de Esperança. Mas exames em sequência mostraram contradições sobre o perímetro cefálico reduzido do feto. O diagnóstico não foi dado pelos médicos, e sim por Joselito, que comparou as medidas do primeiro filho com as da gestação em curso. O casal desconhece as razões da negligência na leitura das imagens ecográficas - se é uma questão técnica ou moral: na primeira hipótese, haveria imperícia, pois as imagens e as medições indicam precocemente a má-formação fetal; na segunda, uma tentativa de impedir que o casal considerasse o aborto como alternativa a uma gravidez não planejada de um feto com singularidades no desenvolvimento.

No dia do parto, Joselito insistiu no direito de ser acompanhante de Maria Carolina, mas o hospital não permitiu a sua entrada - alegava não ter como acomodar um homem em uma sala repleta de mulheres à beira do parto. Sozinha, Maria Carolina pariu Maria Gabriela, e foi ela quem escutou os primeiros sinais de assombro da equipe de saúde, impressionada com as formas da recém-nascida. iii Joselito não esconde ressentimento ao lembrar como recebeu a notícia: "Quando a menina nasceu, toda a equipe ficou emocionada, parecia que tinha nascido um bicho, um animal. Passavam longe do local onde a menina estava, e eu ficava só observando. Era minha filha."

O casal apresenta demandas por reparação - reclama da violação de direitos pela epidemia (planejamento familiar); pela assistência em saúde recebida (proibição de acompanhar o parto); pela forma como foram tratados no hospital (discriminação pela deficiência da filha). Joselito e Maria Carolina usam a linguagem dos direitos: negligência, acesso à informação, planejamento familiar, Lei 11.108 são alguns dos argumentos elencados na narrativa. Mas há um pedido original no texto familiar: "nós queremos o conhecimento de vocês", dizem ao se referir às inquietações vividas pela medicalização da gravidez e da recém-nascida. Há um futuro anterior ao nascimento para a vida da filha que depende do compartilhamento desse conhecimento. O termo 'vocês' se refere às autoridades de saúde, aos médicos e cientistas que anunciam novas descobertas sobre os efeitos do vírus Zika nas criançasiv ${ }^{\text {. O }}$ casal sabe que a informação é um ponto de partida para garantir direitos, em particular o direito à saúde. Mas a correção para a expressão "direito ao conhecimento" é o que gostaríamos de explorar nesta nota, ao compreendê-la como uma categoria política para as incertezas que atravessam a vida de mulheres e homens diante da epidemia do vírus Zika no Brasil.

i Os nomes são verdadeiros. Joselito e Maria Carolina optaram por não guardar sigilo da história. Ao contrário, desejam ser protagonistas na garantia de direitos às famílias afetadas pela epidemia provocada pelo vírus Zika no Brasil. Eles foram os primeiros leitores desta nota. Conhecemos o casal durante o trabalho de campo etnográfico para o documentário Zika, disponível em: https:// www.youtube.com/watch?v=m8tOpS515dA.

ii Em maio de 2016, quase 50 crianças recebiam atendimento naquele Ambulatório de Microcefalia.

iii Maria Gabriela permaneceu sozinha no local, pois não havia outras mulheres em trabalho de parto.

iv $\mathrm{E}$ a nós, como mediadoras de narrativas e mulheres urbanas elitizadas. 


\section{Informação}

O direito à informação é parte substantiva para a garantia da justiça reprodutiva. Sandra Coliver ${ }^{1}$ sustenta que "o direito à informação é um canal pelo qual outros direitos fundamentais podem ser protegidos por tribunais internacionais”. Haveria um patamar mínimo de obrigações para a garantia da liberdade de escolha e para a saúde reprodutiva, sendo um dos critérios a "obrigação afirmativa" de oferecer a informação necessária para que as mulheres possam fazer suas escolhas. Ou seja, o acesso à informação seria um dos componentes para a proteção à saúde, exigindo ações concretas de governos para a sua garantia.

Uma epidemia lança cenários inesperados às políticas da vida² . O caso da transmissão vertical do vírus Zika em mulheres grávidas não envolve apenas a biopolítica de populações em risco (modos de eliminar mosquito ou distribuir água limpa; regulação sobre as formas de vestir ou as práticas sexuais), mas o incerto na ciência e no cuidado dos corpos. Maria Carolina foi diagnosticada como portadora de uma "virose" - a mesma abstração de dores e sofrimentos de Marina do documentário Zika ${ }^{3}$. Virose é uma categoria nosológica de gente sobrevivente às doenças permanentes, como é o caso da geografia da dengue no Brasil e, mais recentemente, da doença do vírus Zika e da febre Chikungunya.

O médico não soube diferenciar virose e febre provocada pelo vírus Zika, e se justificaria pela novidade do vírus no país. Em sua defesa usaria o teste Bolam ${ }^{4}$ - não há negligência se o médico agir de acordo com o esperado de outros médicos em situação semelhante: um vírus desconhecido, uma sintomatologia leve quando comparada à dengue fez com que a primeira geração de mulheres afetadas pelo vírus Zika recebesse o diagnóstico de uma "virose"v. Quando Maria Carolina engravidou, o anúncio da circulação do vírus Zika no Brasil era recente; a hipótese da vinculação entre ele e as alterações neurológicas só foi estabelecida após o nascimento da criança. Por isso, não é apenas a informação sobre os fatos da epidemia ou sobre os efeitos do vírus o que garantiria o conhecimento reclamado pelo casal: nossa tese é que Joselito e Maria Carolina também reconhecem a instabilidade dos fatos e as incertezas médicas sobre os riscos da epidemia, mas ao demandarem "conhecimento" buscam existir em um marco de proteção da vida que se, por um lado, os ignora, por outro, depende da mediação de diferentes poderes e saberes para ser acessado.

\section{(Re) conhecimento}

Uma epidemia provoca os sentidos da vida precária como "uma verdade existencial", nos termos de Judith Butler5. Se considerarmos a potência do vírus, todas estaríamos igualmente em risco de adoecer, pois essa seria nossa vulnerabilidade compartilhada - a da vida precária que nos fragiliza no encontro com os mosquitos. Mas somente algumas mulheres tiveram a vida precarizada pelo assombro da epidemia: mulheres nordestinas, pobres, de regiões rurais em que há intensa circulação do mosquito, dependentes dos serviços públicos de saúde. Das crianças nascidas com a síndrome neurológica provocada pelo vírus Zika, 88\% são da região Nordeste. A concentração se explica por regimes prévios de precarização da vida e não apenas pela "verdade existencial" de que todas seríamos frágeis e sem imunização aos efeitos de um novo vírus circulando no país. ${ }^{\text {vi }}$

"Nós queremos o conhecimento de vocês" é mais do que um pedido de participação em um regime de poder específico; é uma demanda ética por reconhecimento de que os corpos suscetíveis ao adoecimento pela epidemia são vidas já previamente precarizadas por amplos regimes de desigualdade - região, classe e sexo são alguns dos mais marcantes. Há uma despossessão anterior à chegada da nova doença, e por isso a "verdade existencial" da vida precária não atingiu todas as mulheres igualmente. O acesso aos métodos de planejamento familiar ou mesmo ao aborto seguro é uma estratégia de cuidado que, se não compartilhada,

v O mesmo não parece valer para a leitura das ecografias ou para a identificação das alterações neurológicas no feto.

vi Do total de crianças notificadas, esse percentual refere-se apenas aos casos confirmados para a síndrome congênita do vírus Zika. 
deixa alguns corpos mais suscetíveis ao adoecimento que outros - por isso, conhecimento é mais vigoroso do que informação no sentido de capacidade para escolhas, é redistribuição de proteções para uma vida digna.

Há formas sociais de privação, e a pobreza é uma delas, o adoecimento sem assistência é outra. As privações injustas são formas de despossessão que impedem o florescimento de uma vida digna. Joselito e Maria Carolina reivindicam “conhecimento", isto é, acesso a direitos e proteções para uma vida digna. Assim, a metamorfose pelo reconhecimento da despossessão injusta não é para fazer deles indivíduos possuidores de mercadorias, mas sujeitos inteligíveis ao marco de poder que os ignora como vítimas da epidemia. Por isso, haveria uma proximidade entre o conceito de despossessão e de alienação em Marx, dizem Butler e Athena Athanasiou': "os sujeitos trabalhadores estão privados da capacidade de controlar suas vidas, mas também estão impedidos da consciência do subjugo". Querer o conhecimento do outro é rebelar-se à subjetivação política que faz da epidemia um acaso sem responsáveis e universalmente ameaçador.

As condições precárias de vida determinam regimes de susceptibilidade à epidemia; por isso os corpos são afetados de maneira diferente pelos riscos do mosquito ou da transmissão sexual do vírus Zika. Inclusive se submetem de maneira desigual aos efeitos das políticas penais impostas aos corpos: uma mulher grávida e infectada pelo vírus Zika com acesso a métodos seguros de aborto poderá alterar a presunção de que um mosquito provoca igualmente, em todas as mulheres, a "verdade existencial" da precariedade dos corpos. Ou mesmo uma mulher com recursos para terceirizar cuidados e acessar bens sociais básicos como mercadoria (educação, transporte ou saúde) viverá de maneira diferente os deveres de maternagem de uma criança com múltiplas dependências. É o "conhecimento" dessas formas de proteger-se dos efeitos da epidemia que reclamam Joselito e Maria Carolina.

\section{Referências}

1. Coliver S. The right to information necessary for reproductive health and choice under international law. Am Univ Law Rev. 44:1279-1303.

2. Fassin D, Schneider H. The politics of AIDS in South Africa: beyond the controversies. BMJ. 2003;326:495-7.

3. Diniz D. Zika. Brasil: Itinerante Filmes; 2016.

4. Brazier M, Miola J. Bye-bye Bolam: a medical litigation revolution? Med Law Rev. 2000 Mar 20;8(1):85-114.

5. Butler J. Notes toward a performative theory of assembly. Cambridge: Harvard University Press; 2016. 248 p.

6. Butler J, Athanasiou A. Dispossession: the performative in the political. Cambridge: Polity Press; 2013. 